
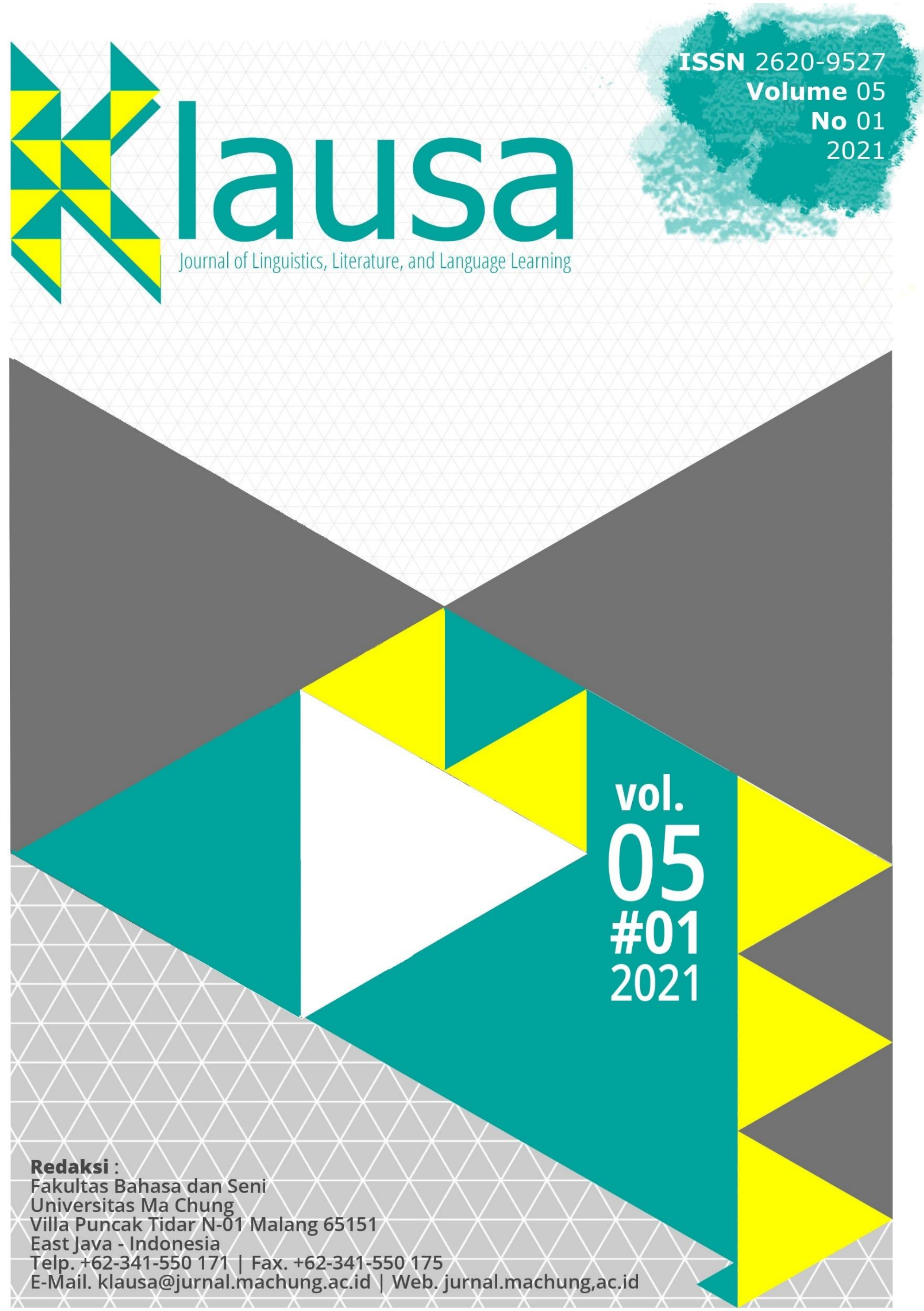
ISSN: $\quad 2301-4822(p)$

DOI: $\quad$ 10.33479/klausa.v4i02

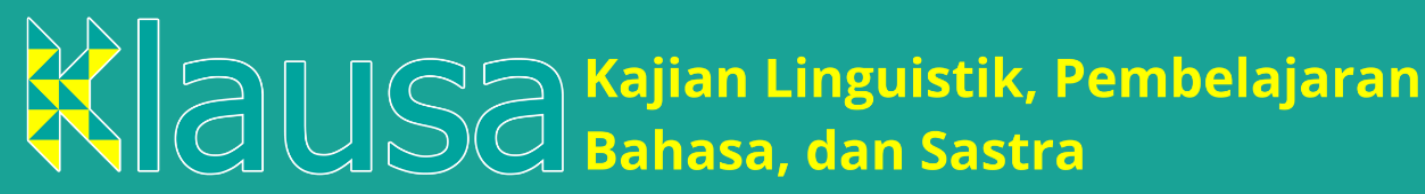

\section{Editorial Team}

$\begin{array}{ll}\text { Editor-in-Chief } & : \text { Dr. Daniel Ginting } \\ \text { Journal Manager } & : \text { Wawan Eko Yulianto, Ph.D. } \\ \text { Editors } & \text { Prof. Dr. Patrisius I. Djiwandono } \\ & \text { Lilis Lestari Wilujeng, M.Hum. } \\ \text { Reviewers } & \text { F.X Dono Sunardi, M.A. } \\ & \text { Dhatu Sitaresmi, MTCSOL. } \\ & \text { Anggrah Diah Arlinda, MTCSOL. } \\ & \text { Yohanna Nirmalasari, S.Pd., M.Pd. } \\ & \text { Prof. A. Effendi Kadarisman, Ph.D. } \\ & \text { Sisilia Halim, Ph.D. } \\ & \text { Dr. Mundi Rahayu } \\ & \text { Dr. Ross Wood } \\ & \text { Dr. Leticia Araceli Salas Serrano } \\ & \text { Faculty of Language and Arts } \\ & \text { Universitsas Ma Chung } \\ \text { Frequency } & \text { The Faculty of Language and Arts } \\ \text { Mublisher } & \text { Ma Chung University } \\ & \text { Villa Puncak Tidar N-01 (65151) } \\ & \text { Malang, East Java, Indonesia } \\ & \text { Email: jurnal.klausa@machung.ac.id } \\ & \text { Twice a year } \\ \text { Address } & \end{array}$




\section{CONTENTS}

FOREWORD

iii

MANAGEMENT OF POLITENESS STRATEGIES AND RHETORICAL DEVICES IN DONALD TRUMP'S SPEECHES DURING THE CONFLICT WITH IRAN: PRAGMATIC VIEW

Khoirun Nisak, Lisetyo Ariyanti

PERBANDINGAN UNSUR PEMBANGUN CERITA NOVEL DAN FILM SANG PEMIMPI

Muhamad Deni Setiawan. 19

HALF-CASTE'S STATE OF LIMBO IN KATHARINE SUSANNAH PRICHARD'S “MARLENE” AND “FLIGHT” (1967)

Laily Ramadhani, Mamik Tri Wedawati. 29

ANALISIS KUALITAS TERJEMAHAN TEKS BAHASA JEPANG KE BAHASA INDONESIA DENGAN BING TRANSLATOR

Wisnu Setya Budi, Febi Ariani Saragih 45

印尼玛中大学汉语学习者词汇学习策略调查研究

Vincentius Valiandy Jiuangga,S.Kom.,MTCSOL 63 


\title{
HALF-CASTE'S STATE OF LIMBO IN KATHARINE SUSANNAH PRICHARD'S “MARLENE” AND “FLIGHT” (1967)
}

\author{
Laily Ramadhani ${ }^{1}$, Mamik Tri Wedawati ${ }^{2}$ \\ 1Universitas Negeri Surabaya, laily.17020154031@mhs.unesa.ac.id \\ 2Universitas Negeri Surabaya, mamikwedawati@unesa.ac.id
}

\begin{abstract}
Half-caste refers to the mixed-blood in Australia who suffer much in their lives. They are not a part of Aborigines nor the Whites. They are not accepted by everyone and being mistreated. They suffer from unfair treatment and are also incapable of making decisions to get a better life. The purpose of the study is to reveal the state of limbo of the half-caste in Katharine Susannah Prichard's "Marlene" and "Flight" (1967). The method used is qualitative by applying Wilson Harris' state of limbo theory on the post-colonialism approach. Limbo is a transition where a person or community belongs in two contexts. There are three characteristics of limbo that are needed to be analyzed in the chosen literary work; anxieties, questions, and conflicts that every person or community cannot embrace. As a result, "Marlene" and "Flight" each have three characters of limbo. "Marlene" demonstrates the half-caste's disrespectful life by being locked in the camp and not able to decide on making their life better. "Flight" demonstrates the three half-caste children that are taken forcedly to the Aborigines Protection Board. These children are locked in the room of the carrier so that they will not run away. Stuck in the camp, locked in the room, and unable to do anything to make their life better defines the limbo state of the half-caste's lives.
\end{abstract}

Key Terms: half-caste, limbo, post-colonialist approach

\section{INTRODUCTION}

Australia has race diversities, including Aborigines, Whites, and even part of Aborigines and Whites, which is called half-caste. Half-caste has been a scandalous topic in Australia. Based on their racial appearance, they are not a part of Aborigines and the Whites. However, their existence could be seen in the discriminations by the Whites. Even though half-caste is born from the Whites and the Aborigines, the Whites are having bad feeling even hatred towards them. There are two factors behind this feeling, are physical 
appearance and social factors. The physical appearance stands for the mixture of a White and an Aborigines, half-caste is considered as a degenerated hybrid. While social factors stand for lack of education, unemployment, and poverty (McGregor, 1993, pp. 54-55).

Half-caste is one of the most underestimated races in Australia, they do not have a natural place to live except in the camp that was built and secured by the Whites. Not only places, but they also do not have any chance to get the same job as the other races. They would only do some jobs which do not give many amounts of money. Even when a half-caste has the same ability and cleverness, he will consistently be underestimated. The tragedy of stolen generation made some of the aborigine mothers who gave birth to a fair-skin baby were not allowed to raise their children. The law in Australia has strictly declared that aborigine mothers are not allowed to raise children.

This study analyzes the half-caste's state of limbo in two short stories by Australian writer Katharine Susannah Prichard with a particular focus on the conflict of half-caste's character chosen. In Prichard's "Marlene" (1967) and "Flight" (1967), Prichard presents a great explanation of how the half-caste's living through injustice and discrimination from the Whites. Their life are all depending on the Whites. However they do not get their rights. In this context, Wilson Harris' theory on state of limbo offers grounds for understanding the condition where a community might feel limb depends on their specific situations.

In this study, each stage presented in the theory will be applied to the Wilson Harris' state of limbo with the half-caste's life condition in "Marlene" and "Flight". Using Wilson Harris' state of limbo, this article presents several questions that must be analyzed: a) how are the half-caste depicted in Katharine Susannah Prichard's "Marlene" and "Flight"? (b) How do the half-caste character's conditions lead to the state of limbo?

Katharine Susannah Prichard was an Australian writer and the founding member of the Communist Party of Australia. Prichard's public position is as both a communist and female writer there. Prichard has published many literary works while she lived from 1883 to 1969; there were thirteen novels and one full-length biography (Hobby, 2016, p. 2). Prichard has a desire to write stories about Australian society, especially the half-caste. "Marlene" and "Flight" (1967) are the examples of her works that will be analyzed. Both of the short stories talk about the half-caste' life. "Marlene" tells about a white Madam, Mrs. Boyd, who looks for her half-caste worker that has not been coming for some weeks to the camp of the half-caste. Mollie, the sixteen years old mixed-race worker, could not make it due to her giving birth. In the journey to find Mollie, Mrs. Boyd is accompanied by another white girl named Miss Ann. There, every half-caste is trying to hide Mollie so that Mrs. Boyd would not meet her. This story focuses on the relationship between the halfcaste and the whites. Some conflicts have taken place in the short story; one of them is Albert -a clever half-caste who cannot get a proper job due to his identity as a half-caste. "Flight" tells about Constable John O'Shea, who is asked to bring three half-caste children to be taken by the Aborigines Protection Board. In his journey bringing the children, 
Constable O'Shea feels uneasy since he is also a father who does not want his children to be taken forcedly. To keep these children, Constable O'Shea brings them to his house and locks them in a room. Constable O'Shea could never let them run away, or else he will be in trouble.

\section{REVIEW OF RELATED THEORIES}

Unfortunately, half-caste's life is not easier either due to their hatred from the whites and Aborigines. Although they are part of Aborigines, they do not treat better than the whites. At least Aborigines do not treat them like a vermin. Half-caste are treated very badly. Not only in their place to live but also their education, even their love life. This condition leads to the half-caste's state of limbo, a transition between two contexts. To define the half-caste's limbo state, the data analyzed will be focus on their characteristics based on the book by A.O Neville titled Australia's Colored Minority.

Russel McGregor argues that the 1920s is when the social anthropologists focused on the functioning of societies and tried to advance no critique of racial science. However, racial science existed right after that year. There was a critique that the criticism of its political misuse overshadowed the concept of race. When World War II happened in Australia, there was an idea of race that applied a strong influence in developing the science of anthropology. Regarding idea, the concept of race was revealed there better than in the area where the guess of racial boundaries was passed in mixed descent people. Even before the 1930s, 'half-caste' had been attracted to the scientist's attention (McGregor, 1993, pp. 51-52). This year, half-caste had been mention in some writing.

Rich Pascal tries to define the half-caste's real identity in literary works by saying that half-caste is about to disappear due to the mainstream of Australia's policies in race, practices, and attitudes. Because of the legal implication, people think the half-caste is not worthy enough as the whites or Aborigines itself. Katharine Susannah Prichard tried her best on writing issues about Aborigines and half-caste. Her works have occurred as the introduction to the people who are not an Abo-reader to understand the half-caste's mainstream society can even be used to change the racial policies (Pascal, 2013). Being a half-caste has been problematic since they do not have a real indigenous identity in Australia.

To define the indigenous identity in Australia, John McCorquodale analyzes the legal definitions of race in his journal (2011). McCorquodale limits his analysis of Aborigines and half-caste definitions in each jurisdiction from the earliest times to the present. As a result, Alfred Deakin from The Commonwealth Attorney-General defined that half-caste was not part of the aboriginal native (McCorquodale, 2011). Half-caste is not acknowledged by the Australian back then. The concept is that the people born with more Aborigine blood are considered aborigine natives. However, the half-caste has fewer Aborigines blood, so they are not a part of aborigine natives. 
This paper will only focus on the specific characters and their conflict in "Marlene" and "Flight" to reveal the half-caste's limbo. Due to Mollie's problem with giving birth at such an early age, Albert's difficulty getting a job even the marriage he wants, and three half-caste's children taken away from their families to be sent to the Aborigines Protection Board. The revelation will be based on a state of limbo's characteristics; anxieties, questions, and conflicts.

\section{Half-caste}

Half-caste is derived from the Latin adjective castus, which means pure or unpolluted to its subjects. Modern English takes this word 'chaste,' and then half-caste is translated as a child of linguistic miscegenation in Portugal and Britain's empires. English then adapted this term by adding the 'e' in the final. The term is spelled as 'caste'; it refers to the person who has a mixed percentage of European and Indian (Douglas \& Ballard, 1940, p. 328). Half-caste stands for the mixed-race, mostly European and Indian.

In the 1930s, a 30,000 population of mixed White and Aboriginal descent called a half-caste in Australia. Half-caste is also known as mixed-blood, part-Aborigines, and partWhites, or colored folk. However, these terms have a different meaning. Half-caste stands for the people who have an equal percentage of Aboriginal and non-Aboriginal ancestry -it could be Whites. Colored folk is divided into three; three-quarter caste, quarter-caste (quadroon), and eighth-caste (octoroon). These three means that each of them belongs to three-quarters, one-quarter, or one-eighth of Aboriginal ancestry (Neville, 1947, p. 3). In Australia, the problem mainly focuses on half-caste only. They are being underestimated in every realm. Half-castes try their best to improve themselves economically and socially. However, they give up easily since they are not wanted by residence, especially the town.

Back then, there was an assimilation project made by the States. The assimilation here stands for how half-castes are being adopted by the Whites (Neville, 1947, p. 167). It is intentionally done because the State wants the tribe to be melted in a pot. The children are taken forcedly and being adopted by the Whites. The purpose of assimilation is to support the children through adolescence to adulthood. The State wants the children to have their rights to get a better future. Although the purpose is good, it has to separate the children from their biological parents. This tragedy is called the stolen generation.

The characteristics of half-caste are living in an inappropriate camp built near the rubbish dump or riverbank. They do not live healthily since there is no decent food for feeding; they have a health disease such as malnutrition, a skin disease caused by exchanging clothes, digestive pains, and enteritis. They do not get a chance to be educated than the Whites; they do not even have a chance to get a proper job (Neville, 1947, pp. 133-145). These conditions have limb the half-castes; they even feel how they are not unwanted by the others, especially the Whites. 


\section{State of Limbo}

The term of limbo comes from Wilson Harris, which he thought of as limbo imagination that is demonstrated as representing the inner universality of Caribbean man. It is a concept represented by Harris in the waves of migration that have lived on America's shores (Hunte, 2017, p. 45). Harris defines limbo as "a certain kind of gateway or threshold to a new world and the dislocation of a chain of miles (Ashcroft et al., 2013, p. 379)". Limbo gives us the impression of being in two contexts in which the people are unsteady and limb between those two.

Limbo derives from limbo dance, a known feature in the Carnival life of the West Indies. The limbo dancers have to conquer the bar by continuously lowering their bodies without touching it; they remain through the bar with spread-eagled limbs they pass like a spider. Truthfully, limbo was born on the slave ships of the Middle Passage. According to Bill Ashcroft and others, the folk's limbo imagination consists of a strong inner recreative response on violations of slavery and arrangement and victory (Ashcroft et al., 2013, pp. 378-382). Harris demonstrates the critical thing of limbo imagination on the stamp of the spider metamorphosis, which is depicted in the shaping of every community that appears sea-change. Harris calls upon the resonance of limbo with term limb to show the flexibility of common descendants in devastation and deep trauma. Harris' idea on the limb body parts stands for reminiscent of a slave's imprisoned body, striving for space, and the slave's condition while being threatened is similar to a spider. The position of a spider when it is standing is spread-eagled and low to the ground. It demonstrates how suffering the slaves while passing the Middle Passage, and it is their consequence for their journey over water while having their bodies hanging in space and trapped in time. They will get a sea-change, which means a specific alternation merely can be done by the survivors. The appeal of limbo imagination through limb/limbo metaphor relies on the main idea of time-travel and mutilated bodies to depict the community above the traumas in the past (Hunte, 2017, p. 46).

Limbo expression invokes the afterlife province, which some religions have to believe in it. It labeled for the souls who neither go to heaven or hell. It shows metaphorical comparison in waiting transitional state that contrasts to immigration on a type of death or rebirth. This idea demonstrates the perspective of immigration and cultural alteration in limbo. It shows the burdensome and hurtful process where the identity is being negotiated (Catalano et al., 2016, p. 144). Backed up by this background, the characteristics of a limbo state can be seen from the person's condition whether he has anxieties, questions, and conflicts as he is incapable of finding comfort that he can embrace (Al-Saidi, 2014, p. 103).

\section{METHODOLOGY}

Regarding the purpose of the study is revealing the state of limbo of the half-caste, a qualitative method is required to get the objective and specific result. The qualitative 
method is being needed to analyze the sentences, paragraphs, and dialogues in the short stories selected. The sentences, paragraphs, and dialogues needed are the one which shows the half-caste's state of limbo. To gain the data, reading the short stories "Marlene" and "Flight" (1976) by Katharine Susannah Prichard have to be done and then analyze the specific sentences or paragraphs needed. Based on the characteristics of the limbo state, there are five characters in total will be analyzed. These five characters are Albert and Mollie in "Marlene" (1967) and three half-caste children named Mynie, Nanja, and Coorin in "Flight" (1967). The characters selected are having anxiety, conflict, and questions that become the characteristics of limbo. The conditions they have will answer how half-caste characteristics bring them to the state of limbo using postcolonialism theory. The citation of the sentences, paragraphs, and dialogues will be showed to become the data.

\section{FINDING AND DISCUSSIONS}

\section{A. The half-caste's characters state of limbo}

The half-caste's characters state of limbo in "Marlene"

"Marlene" shows an excellent example of introducing the half-caste who lives in the camp. There are several characters; however, the analysis will be limited to two characters. These are the analysis of the half-caste's characters that will lead to the state of limbo:

Albert's state of limbo based on three characters

\section{Anxiety}

"He's sore because he can't get work and the Protector won't let Penny Carnarvon marry him," Ruby said. "Penny in service, and she's such a good servant they don't want to lose her. But she's fond of Albert. She says she'll learn the Protector." (Robertson, 1967, p. 118)

As a young half-caste, Albert has someone he likes. He wants to marry her, and the girl he likes is Penny Carnarvon, who works for the Protector. A protector is police from the Whites who protect the natives (Neville, 1947, p. 214). Quoted from the data, Albert has anxiety that he cannot achieve what he wants. Including the job and the person, he likes to marry. The reality hits him since most of the jobs are given to the Whites, neither Aborigines nor half-castes could bear but accept it.

The other reason that might interfere with Albert and Penny's marriage is the inability of a young couple to live after marriage (Neville, 1947, p. 188). Well, we know that marriage has many kinds of difficulties. Including how to make money for a living, and a newlywed is familiar with the small fight. Not only financial but emotional control is needed in marriage life. If Albert decides to marry Penny at the end, he might get anxious because he cannot give a living to his wife. Because he has no job, he might have difficulty maintaining his wife outside the settlement. The probation is made to prevent the halfcaste's disadvantages on their life after marriage. 


\section{Questions that the character could not embrace}

"It's hard on Albert not being able to get work, Mrs. Boyd," Ruby expostulated. "He's real clever: can read and writes as good as any white man. When he went to school, he could beat any of the boys."

"Lot of good it's ever done me," Albert sneered. "If I'd been myall l'd've had a better life. The blacks of any tribe share all they've got with each other. The whites grab all they can for themselves-and let even their own relations starve." (Robertson, 1967, p. 117)

Albert's difficulties in getting a job are an unending story. Truthfully, Albert is capable of doing many things. He is gifted by his cleverness, which the other half-caste do not have. Most of the workers are whites because Albert is mixed-race, he has some problems about getting a job. The reason behind it is because the Whites do not want the half-caste to be stand out, especially when it comes to a clever half-caste who could beat the Whites down (Neville, 1947, p. 196). Whites want to stand out more since they feel superior; their dignity will not let the half-caste have a better job than them.

Truth hits the reality; whenever a half-caste is more capable than the Whites, they would never get the same wage as the Whites. How clever or how capable the half-caste is, they will get a lower wage than the Whites. The reason is that they do not only want the half-caste to get the same position as the Whites. Half-caste is considered as the degenerated hybrid over the Whites and the Aborigines.

\section{Conflict}

"Funny, isn't it?" Albert's lounging, graceful figure tilted back as he gazed at her. "You're the granddaughter of one of the early settlers who shot off more blacks than any other man in the country. Mrs. Jackson is the granddaughter of one of the survivors and related to the best families in the district. But you've got the land and the law on your side. They put the dogs onto her if she goes round the homesteads asking for a bit tucker or old clothes.

"And this is the only spot where we're allowed to camp in the district."

"Something will have to be done about it," Mrs. Boyd declared.

"What?" Albert demanded. "All the land about has been taken up. It's private property now. We're not allowed to work in the mines. We're not allowed to sell the fish we catch-not allowed to shot or trap. They don't want us on the farms. They won't let us work on the roads. All we're allowed to do is draw rations and rot though there is some talk of packing us off to one of those damned reservations 'where diseased and dying remnants of the native race are permitted to end their days in peace'. Excuse me quoting the local rag." 
"You can't say I haven't tried to help you," Mrs. Boyd protested. "I've always given you work on my farm when I could."

A wry smile twisted the young man's mouth. "And paid us less than half you'd have had to pay the other workers." (Robertson, 1967, p. 116)

As one of the clever half-caste, Albert gives his voice about the injustice which halfcaste gets from the Whites. Half-caste is placed in the camp, which is near the bank or the hill. The camp setting in "Marlene" is on the hillside and crouched among the rocks and wet undergrowth. Making a camp for half-caste is a kind of isolation (Neville, 1947, p. 135). Half-caste is a taboo thing which the Whites do not want to get bad influence from them. While staying in the camp, they do not get healthy food and an excellent place to live. Albert and the others suffer from wetness all the time the rain is falling hard.

The other thing that can be seen from the data is the half-caste does not worth as the other workers -that might be the Whites or Aborigines. Then, there were many excuses not to pay the half-caste as they worth. The Whites believe that a white worker may worth twice more than a half-caste (Neville, 1947, p. 193). There is much determination of why the half-caste does not get the price they worth. For example, the half-caste does not know the value of money. Also, the half-caste is paid that much due to their consistency in working. Some half-caste might be more competent than the Whites since they are used to be a labor. However, their condition of not knowing how worth the money wage leads them to the consistent money wage they get. There are not many half-castes aware of this issue; he knows that injustice will always follow the halfcaste regarding Albert's cleverness.

Mollie's state of limbo based on three characters

\section{Anxiety}

"Let me see the child," Mrs. Boyd demanded: turned her horse and rode to Mollie.

"She's very little and red," Mollie apologized, tenderly lifting the dirty shawl that covered the baby. (Robertson, 1967, p. 119)

Mollie, who has a baby at such an early age, would have anxiety. Even though she feels fine having many relationships with some White guys in the city, she could not hide her feelings. In the dialogue above, Mollie apologizes for how tiny and red her baby is. Since she is only sixteen and has a baby already, she has the anxiety of how her baby will grow with her, who is still a growing teenager.

Teenagers like Mollie would have done sex; however, they do not know about raising kids. Mr. Neville said in Australian's Colored Minority (1947), "I never heard of but one colored girl being induced to enter a house of ill-fame. Some of those who bore infants fought gamely through life, adored their offspring, and swore to protect them from a similar fate - becoming better women, good mothers, and eventual wives (Neville, 
1947, p. 184)." Despite Mollie's young age, Mollie has excellent faith in giving birth. She does not even do an abortion and bravely gives birth to her baby.

\section{Questions that the character could not embrace}

"Hullo, Mrs. Boyd!" A girl in a pink cotton frock stood in the opening of a wurley behind the horses. A pretty little thing, sturdy and self-possessed, but rather pale, she stood there, a small bundle wrapped in a dirty shawl in her arms.

"Mollie," Mrs. Boyd gasped. "Have you been getting a baby?"

The girl nodded, smiling.

"But you're only a child," Mrs. Boyd cried. "You're not sixteen."

"I was sixteen last month," Mollie replied calmly.

"It's scandalous," Mrs. Boyd exclaimed indignantly. "Who's the father?"

Mollie's eyes smiled back at her. "I been going with two or three boys in town." (Robertson, 1967, p. 118)

This part talks about the question that Mollie does not answer. While Mrs. Boyd tries to look for Mollie, the other half-caste hides her well. Then, Mollie appears in a condition after giving birth. What makes it scandalous is Mollie does not know her baby's father since she has been going out with two or three boys in town. If it is about boys in town, it means that the boys are Whites. Since the half-caste are not permitted to go outside the camp or their work field, it is possible to say that the baby's father is a part of the Whites.

The mixed-race girl has known and acquainted with the white boys since they are taken to the institutions early (Neville, 1947, p. 45). The girls befriend the whites, making them associate with the whites more than the mixed-race boys. Since Mollie has been out with some boys, she could not answer Mrs. Boyd's questions well because Mollie herself does not know who exactly her baby's father.

\section{Conflict}

"Mollie," Mrs. Boyd gasped. "Have you been getting a baby?"

The girl nodded, smiling.

"But you're only a child," Mrs. Boyd cried. "You're not sixteen."

"I was sixteen last month," Mollie replied calmly. (Robertson, 1967, p. 118)

This part talks about the conflict where a teenager should not have given birth. Mollie, a sixteen-year-old teenager, just gave birth while her friends might not have done that yet. Especially Mollie is a half-caste, which means she does not have much knowledge about sex. In Australia, the mixed-race girl is the kind of who will not go near the boys regarding her shyness. 
The White girls have more knowledge about sex matter than the half-caste (Neville, 1947, p. 183). Half-caste's girl would never go near the boys except if the boys first approached her. In Mollie's case, she works all the time in Mrs. Boyd's place. She only has a chance to go to the pictures on Saturday night with Mr. Edward's accompaniment. Not only going to the town, but Mr. Edward will also send her back after the picture is finished. However, Mollie does not return on that day. Mr. Edward even waits an hour for her. Here is the proof of Mollie's conflict of being tempted by the boys in the town.

The half-caste's character in "Flight"

"Flight" tells about a constable in Australia who is obliged to bring three half-caste children to the station to be taken by the Aborigines Protection Board. The children's names are Mynie, Nanja, and Coorin. Here are the data that proves these children's character based on the state of limbo:

\section{Anxiety}

Each little girl was strapped one to the other. Their wrists were tied together. Mrs O'Shea hovered over them, smiling and motherly, trying to reassure them. She could not bear to see these children so scared and dumb. Such skinny little things, they were, with great brown eyes and curling lashes, blackish-brown tousled hair, and gina-ginas, no more than scraps of faded blue cotton stuff, on their meagre bodies.

The room was lock-up in all but name, kept for more respectable prisoners. There was a chair and table in it and a bed covered with blue grey blankets. The window had no glass, but was double-crossed with barbed wire.

There was no way the half-castes could get out when the door was locked. Mrs o'Shea told herself. So she took the law into her own hands: kneel down, and with firm white teeth unfastened the leather thongs which bound them: undid the strips of rawhide biting into those slim brown wrists. (Prichard, 1967, p. 30).

These three little mixed-race girls, the Constable O'Shea, takes are being abused not to run away. Abuse is a familiar term in the process of the stolen generation. The data from S. Gilbert's journal entitled "Living with the past: the creation of the stolen generation positionality" said there are about $28 \%$ of the stolen generation who convey to the Inquiry into the Separation of Aboriginal and Torres Strait under Children from their families stated that they were getting physical abuse (Gilbert, 2019, p. 3). In "Flight", Mynie, Nanja, and Coorin get abuse from Constable O'Shea due to his frightened of the half-caste might run away. The data above shows that they are being tied with leather thongs on their wrists. They are also being locked in a small room that looks more like a prison.

Here, the half-castes feel anxiety since they are brought up by the Constable and locked in a small room. They are only children who should not be treated like that. 


\section{Questions that the characters could not embrace}

It was Mrs O'Shea who discovered the three small half-castes, crouched together and staring at her, wide-eyed and woe-begone.

'Oh, Jack,' she exclaimed, 'the poor little things! What are you going to do with them?'

What do you think?' O'Shea asked impatiently. 'Keep them for pets?'

His daughter guessed just what had happened. They queried maddeningly.

'Did you give them a ride on your house, Daddy?'

'Why can't we have a ride on your horse, Daddy?'

'Want to sit up behind you on Chief, too, Daddy!'

'Want a ride...'

'Can't I have a ride, too, Daddy?'

The half-caste's gazed at these other children with amazement. How was it possible for them to talk to the policemen so cheekily and light-heartedly? (Prichard, 1967, p. 28)

The data is set in the house of Constable O'Shea. The half-castes are amazed by the constable's children who ask their father nonstop without taking a breath mischievously. It can be seen that the half-castes also have questions towards the constable on where he will bring them. However, due to the charismatic Constable O'Shea, they do not brave enough to ask. The half-caste only sticks themselves on the Constable O'Shea when brought from the station to his house.

\section{Conflict}

Constable O'Shea resented having to pick up half-caste's girls and send them down to government institutions at the request of the Aborigines Department. He considered it no job for a man who had to maintain the prestige of the force and uphold law and order in an outlying district.

But he had a received instructions that three half-caste female children on Movingunda were to be sent down by the train which passed through Lorgans on the eight of the month. So there was nothing for it but to collect the children, and hand them over to the other who would be on the train (Prichard, 1967, p. 25)

Here is when Constable O'Shea is taking the half-castes. Regarding the task that Constable O'Shea gets, he is asked to pick them up and send them based on the demand. 
The conflict is about how the half-castes will be the stolen generation once Constable O'Shea picks them up.

Stephen Gilbert, in his journal, defines there is a physical removal in the stolen generation (Gilbert, 2019). A physical removal contains removal from the families, which Mynie, Nanja, and Coorin have felt until Constable O'Shea takes them. The legislation allowed the physical removal from their original families to take the stolen generation from their families. Once the children are taken from their families, they are labeled as the "stolen body". The Aborigines Protection Board takes these stolen bodies and cannot return them to their families ever. This tragedy brings every stolen generation and their origins families' trauma.

The children of stolen generations are the most ironic things ever. They are taken since they were little and not able to return home. If the adult has a chance to come back to where they live, children do not have any chance for it (Read, 2006, p. 3). They are brought to a new place at such a young age, even they would forget about who their families are. It is the conflict that Mynie, Nanja, and Coorin will have after being picked up by Constable O'Shea.

\section{B. The half-caste's state of limbo}

Albert, Mollie, and the three mixed-race children give the impressions where the half-castes always have conflict. Especially with the Whites. If Albert has difficulties getting a job, and Mollie has a baby and does not know who her baby's father is, the three mixedrace children will be taken somewhere they could never return. All of the reason behind of this tragedy is the Whites. The Whites take every job vacancy, manipulate the halfcaste, and even make their life more difficult.

Not only the young half-caste suffered because of the Whites, but the old halfcaste suffered too. "Cooped up in the city-with a lot of low-down old women treatin' me like dirt. I've always kept myself to myself. I've always been respectable, Miss Ann (Robertson, 1967, p. 115)." This quotation tells us how no one, even the half-caste itself, has ever respected the half-caste.

Mrs. Boyd and Miss Ann are manipulating the half-caste in "Marlene". The truth hits them late, and they were being kicked out of the camp. No matter how kind Mrs. Boyd is, she is the one who insists on kicking them out from their only place to live. "The sooner they're cleaned out of the district, the better," she said viciously. "They're an immoral lot, these half-castes."... The camp on the hillside was moved on before the end of the month (Robertson, 1967, p. 120). While trusting Mrs. Boyd, the half-caste's trust is betrayed.

Another example comes from the mixed-race children locked up in a room in Constable O'Shea's house. Not only having anxiety but also the children stuck where they stand. "There, now,' she said cheerily, 'you'll be good girls, won't you? You won't try to run away? The Boss'd kill me if you did. (Prichard, 1967, p. 30)' the quoted dialogue is the 
utterance of Mrs. O'Shea, who wants to give the children a place to breathe by loosening the strips on their wrists. However, Mrs. O'Shea's utterance might frighten the mixed-race children. Even though the strips do not linger in their hands, the utterance keeps them thinking about two possibilities.

Here the state of limbo can be proved. In "Marlene", the half-caste can only take things no matter good or bad it is. They are not responsible for any decision since the Whites, and the Protector will keep them in line. Albert could not change any condition of his; no matter how clever or capable he is, he will stay in the line. He is not allowed to marry the woman he loves due to the Protector's decision to look after Penny from quitting the job. Because having a job is so complex, due to the rules that the half-caste is not allowed to work in roads, farms, mines, even they are not allowed to sell fish they catch. The half-caste is manipulated by being forbidden to work in specific places but do dirty jobs.

Not only manipulated but also disrespected. It happens to Mollie, where Mollie gives her baby's name Marlene. The name is taken after the great Hollywood artist named Marylyn Monroe. "The exotic film-star, and that baby in this dump of outcasts -what an indictment! (Robertson, 1967, p. 120)" The utterance demonstrates how Mrs. Boyd and Miss Ann dislike Mollie's decision to name the mixed-race baby.

While in "Flight", the limbo can be seen when Constable O'Shea brings the mixedrace children from the station to his house. The children who do not know anything have been taken by the legislation to be taken to the Aborigines Protection Board. To keep the mixed-race children safe, Constable O'Shea brings them to his house. However, the mixed-race children are being locked in a room. They are stuck and incapable of running away. It can be seen that they want to be free, but they cannot be accessible due to Mrs. O'Shea's utterance. Here is the process of the physical removal of the origins family where the stolen generation happens. Whatever the condition is, the mixed-race children could not run away because they know they will be taken somewhere they could not return to their own family.

\section{CONCLUSION}

Limbo that stands for a transition between two contexts has depicted well in "Marlene" and "Flight" by Katharine Susannah Prichard to explain the half-caste's condition. Half-caste, as the only race being disrespected in Australia, has been suffering in their lives. As the mixed-descents, half-caste has a stereotype of always obey the Whites. Especially when the half-caste only has Whites as the only agent that they can believe. From the Whites, the half-caste can work. Although the work is not valuable, they can earn money from it.

"Marlene" tells about how the half-caste lives in the camp. The state of limbo can be seen from the way they cannot go everywhere and stay in the worst place ever. The half-caste might want to go over the hill and look for the right job for them. However, the 
protection of them is too much. The limbo state is demonstrated by their condition, which is not able to do what they want. The half-caste stands on two transitions, but they could not step on both either. They are stuck in the middle and not able to do things that could make their life easier.

"Flight" tells about how the half-caste children being taken by Constable O'Shea to be transferred somewhere by the Aborigines Protection Board. They are the proof of the stolen generation who cannot run away from the place they are being placed ever since they are being removed from their original family. The state of limbo can be seen from their behavior which only obeys Constable O'Shea and his wife. Although they are obeying, inside, they might be wondering where they are taken to.

The state of limbo defines the half-caste's life by explaining how suffering they are. Half-caste is insisted on staying in the dark, no matter their faith, to go outside and find something better. The half-caste is stuck and not able to take a further step. These tragedies will bring trauma to every half-caste, and the wound will be stuck on them forever. 


\section{REFERENCES}

Al-Saidi, A. A. H. (2014). Post-colonialism literature the concept of self and the other in Coetzee's waiting for the barbarians: An analytical approach. Journal of Language Teaching and Research, 5(1), 95-105. https://doi.org/10.4304/jttr.5.1.95-105

Ashcroft, B., Griffiths, G., \& Tiffin, H. (2013). The Post-colonial Studies Reader. In Year's Work in Critical and Cultural Theory (Vol. 21, Issue 1). https://doi.org/10.1093/ywcct/mbt009

Catalano, T., Fox, J., \& Vandeyar, S. (2016). Being "in a Limbo": Perceptions of Immigration, Identity and Adaptation of Immigrant Students in South Africa and the United States. Journal of Language, Identity and Education, 15(3), 137-150. https://doi.org/10.1080/15348458.2016.1165099

Douglas, B., \& Ballard, C. (1940). Foreign Bodies.

Hobby, N. (2016). Boundary-rider ?: the early Katharine Susannah Prichard on the edge of fiction and autobiography. 10(July), 857-860.

Hunte, N. (2017). CONCEPTS OF A CROSS-CULTURAL IMAGINATION: WILSON HARRIS'S CRITICAL VISION AS A WAY OF READING NARRATIVES OF MEMORY. Journal of Chemical Information and Modeling, 53(9), 1689-1699.

McCorquodale, J. (2011). The legal classification of race in Australia. Aboriginal History Journal, August 1983, 7-24. https://doi.org/10.22459/ah.10.2011.02

McGregor, R. (1993). Representations of the 'Half-caste' in the Australian Scientific Literature of the 1930s. Journal of Australian Studies, 17(36), 51-64. https://doi.org/10.1080/14443059309387130

Neville, A. O. (1947). Australia's Coloured Minority: Its Place in the Community. Currawong Publishing Co. https://collections.museumvictoria.com.au/items/1496210

Pascal, R. (2013). THE PASSING OF THE HALF-CASTES : GAVIN CASEY , LEONARD MANN AND THE POSTWAR'HALF-CASTE' NOVEL.

Prichard, K. S. (1967). Flight.

Robertson, A. and. (1967). HAPPINESS Selected Short Stories by Katharine Susannah Prichard. 
44 | DOI: 10.33479/klausa.v4i02.408 